affords distinct evidence of a persistent notochord, with the arches alone calcified; and as three Hybodont pterygo-quadrates of Liassic and Wealden age appear to be destitute of an articular facette where contiguous with the post-orbital region of the cranium, there is also a corresponding indication of progressive development in the mandibular arch. The author also pointed out that the differences between the anterior and posterior teeth are more marked in $H$. dubrisiensis than in any of the earlier forms of which satisfactory remains are known, and concluded by suggesting that future research in regard to structures other than teeth will probably lead to the generic subdivision of the multitudinous forms hitherto grouped under the name of Hybodus.

\title{
CORRESPONDEINCF.
}

\section{THE SURVEY OF WESTERN PALESTINE.}

Sir,-Permit me to offer two or three observations as regards matters of fact in reply to the criticisms contained in the review of the "Geological Memoir on Arabia Petræa and Palestine." The reviewer says (p. 229): "Fossils appear to be rare throughout the [Cretaceo-Eocene] series-the Expedition does not seem to have discovered any in fact." This is really not so. We brought home a good many specimens, and I placed them in the hands of Professor Sollas (who was so good as to describe the Carboniferous forms) for determination. But owing to causes, doubtless quite sufficient, I did not receive the specimens back till too late for publication. Since then Prof. Sollas has informed me that there were no new forms amongst them, as they had already been determined by Lartet and others. It is only known to those who have made the attempt, how difficult it is to collect fossils and specimens when on a journey on camel-or horse-back, through the desert under a temperature of $80^{\circ} \mathrm{Fahr}$. in the shade, and $112^{\circ}$ in the sun.

Again, in speaking of the "Calcareous Sandstone of Philistia," the reviewer states, "No thickness is assigned to this deposit." I have only to say in reply that owing to the extent to which Philistia is overspread by the deposits of the 220 raised sea-bed-and with loam-the sections of this sandstone are very rare; nor had we any opportunity of observing the junction of the sandstone with the Nummulite-limestone. Both thickness and relations, as they are inferred by me, may be gathered from the horizontal section, No. 1, across Palestine. It is not improbable the formation has a thickness of 300 to 400 feet. The reviewer seems to have overlooked the fact that this sandstone appears to have its equivalent in the series at Mokattam Hill, near Cairo, described by Schweinfurth.

3. As regards the question, "What has become of the materials which have been removed from the surface of the drainage area of the Dead Sea?" (p. 231). As this basin never had an outlet, there can be only one answer (which appears to me self-evident)-that they are either used up in the terraces - or are spread over the floor of the Dead Sea and Jurdan-Arabah Valley. The bottom both of 
the Dead Sea and of this valley are covered by alluvial deposits. What the thickness of these may be no one knows; nor can the question of the depth to the solid rocks below the alluvial materials be solved except by extensive boring operations. In my opinion the depth is very great; and if this be so, the answer to the question of the reviewer is plain, - at least, this is the only answer I conceive possible.

Duxfaxwaghy, 12 th May, 1886.

Edward Holl.

\section{THE DEVELOPMENT OF THE NOR'TH AMERICAN CONTINENT.}

SiR.-There are no questions in Geology more important and more fascinating than those of Palæo-geography. All geologists must be grateful to Prof. Hull for the light he has shed upon them. But, also, there are no questions which are more difficult, and the solution of which is more illusory. I would not again trouble you on this subject except to correct what seems to me a grave misconception on the part of Prof. Hull, ${ }^{1}$ which lies at the basis of nearly all the difference $\theta$ between us.

He refers to an ideal section of the Palæozoic rocks on p. 288 of my "Elements of Geology" (being a section from Canada through New York to Pennsylvania), as indicating continued subsidence of sea-bottom and retreat of shore-line northward during the Palæozoic period. This interpretation is the very opposite of that usually given by American geologists. Perhaps the mistake, if it be one, is partly due to bad drawing. In order to bring all the Palæozoic strata within the compass of a small figure, the southward dip is enormously exaggerated. In fact, the strata are nearly level, the average dip being probably not more than 15-20 feet per mile. The successive appearance of younger and younger rocks as we go southward is supposed by all American geologists to indicate a gradual elevation of the Canadian land-mass of that time, and a consequent advance of the shore-line southward with steady increase of land. This is seen at once if the section be drawn with smaller dips and leaving out details (Fig. 1).

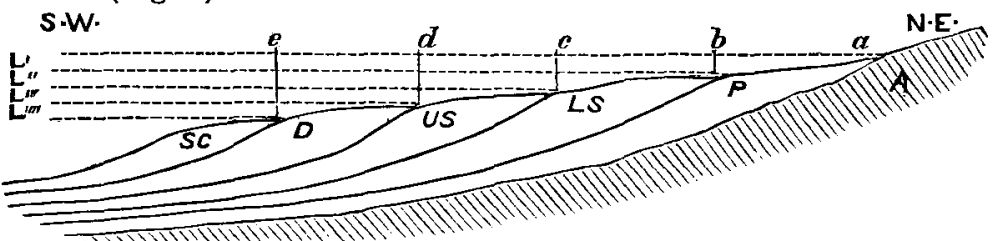

FIG. 1.-Generalized N.E. and S.W. section from Canada through New York to Pennsylvania. A. Archæean. P. Primordial. L.S. Lower Silurian. U.S. Upper Silurian. D. Devonian. S.C. Sub-Carboniferous. a $b c d e$ successive shore-lines. $l l^{\prime} l^{\prime \prime} l^{\prime \prime \prime} l^{\prime \prime \prime \prime}$ successive sea-levels.

The western shore-line of the eastern land-mass was, on the contrary, nearly stationary, and hence the prodigious thickness of Palæozoic sediments in the Appalachian region. Even here, however,

1 See Prof. Hull's letter, GEOL. MAG. April, 1886, p. 189. 